\title{
A NOTE ON
}

THE FUTURE OF MINTNG BETWEEIN RLBY AND THE KISKOKNIM RIVBR, ALASKA

Mining in the district that $11 \mathrm{er}$ between Fuby and Takotna

has been confined to the plecer operations in the fruby-Long-Poorman

Distriot and the Innako Distrlat. There has been no interest shom,

due to the lack of transportation fasilties, in prospecting for

lode depostte. There are many unexplared placer creeks in the area

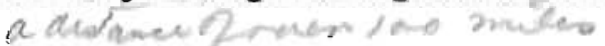

between Poorman and ophir; this area being inaccessible to river

transportation. The Alaglo Road Commisgion have kept up a trail

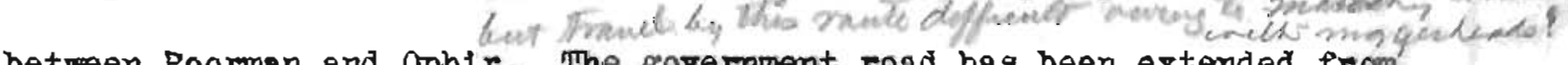

betwen Poorman and Ophir. The goverment road has been ertended from

Paby to Greenstone, a diatence of 35 miles. This year the road bag

been completed between Ophir and Takotma; Takotma is acceasible to the

Euskokurm River by the Pakotna River. The eventual completion of the

roed from Greenstone to Ophir should stimulate interest in prospect-

Ing along the route. The time is perhaps far diatant, but it is of

Interast to stady some of the aspects of the district for fature

mining activity.

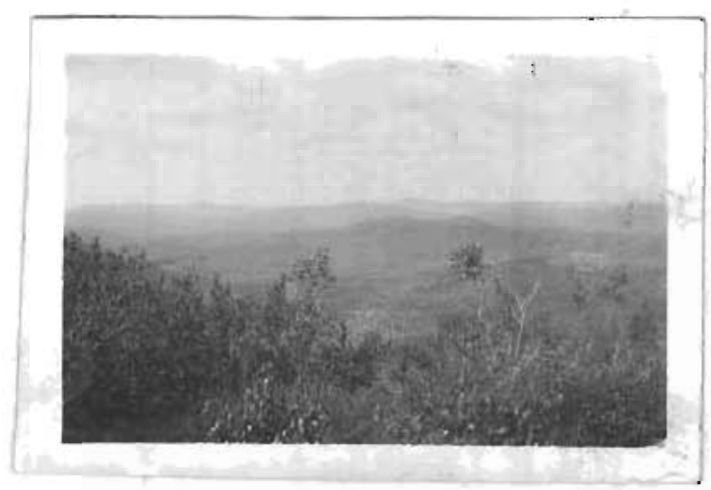

Scene alone Lonc-ophir trail. 
This area l1es south of Firby, on the Yukon RIver, to Takatna, on the Takotne Hiver, along the goverament road and the trail, connecting the goverment roads, between Greenstone and ophir.

Bulletin 754, J. S. Geological Survey, "Whe fuby Kuskokwim Region Alaska," by J. B. Mertie, Jr. and G. I. Herrington, discusges the general geolagy of the diatrict. A geologic map accompanies the report.

Interest in placer mining in the vicinity of Ruby ia wantag. There are future dredging possibilities on Loug Creek and its tributaries. According to locel opinion, interest in dredging is prevented by some of the ownerg on long Greek holding out for a largo eagh advance for options on their clalms.

It is reported that the dredge on Candle creek has ceased in 19.40

operations. The Gulnan and Ames dredge on Ganes Creek may close down at the end of this segson. It is notural to asgume that these operators will intestigate other dredolne possibilities in this district.

There ere mong unprospected creeks that ofll be made accessible With the completion of the proposed road. Prospecting for lode mines Wil be stimlated as the districts become avallable to transportation. The areas adecent to the grantite intrusions shovld recelve the primary attention of the prospector.

Cripple Mountain offers possibilities for prospecting. Velns of stibnite with some cinnabar, and arsemopyrite were observed. Laxge 
pleces of magnetite are found in the placer operations around Cripple Mountain. Peridotite dikes, conslating moinly of olivene and blotite occur at the head of Itttle Eldarado.Creak. Mr. William Senenstkos hes discovered a 3-1nch veln of quartz containing arsenopyrite on his placer fround. As there is no development work the extent or relationships are not known. A sample of this occurrence ws taken. The assay showed: Gold...0.72 oz. per ton. Silver... 0.10 oz. per ton.

The ares is thinly populated at the present time. There is no active prospecting activity. The occurrence of basic dikes in a region of acid intruaites may be good eridence of ore deposition. 

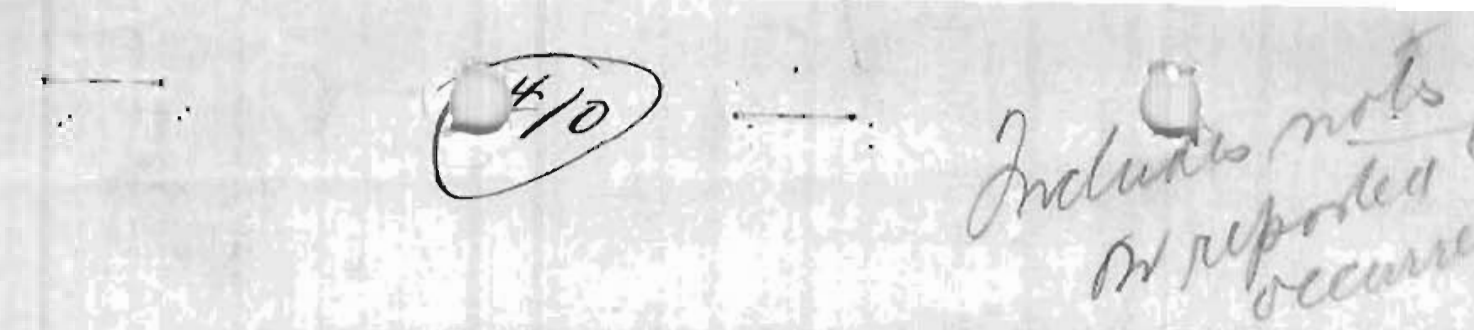

MISGETIANEOUS GEOIOGIC NOTES ON THE RUBT MINING DISTRICT, AWASKA

SPRING DEPOSIT

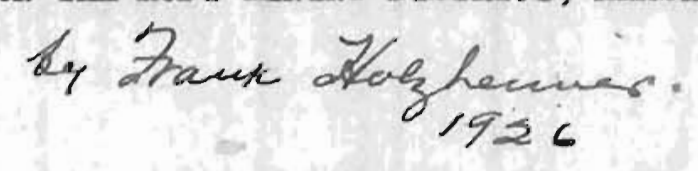

Twelve miles from Ruby, on the east side of the Fabj-Lons road, is a mound that stands out prominently in the topography. The mound is know locally, because of its nature, as a gmell erater. The surrounding country is covered with vogetetion and grevel so that the structural relationghips cannot be obsenved.

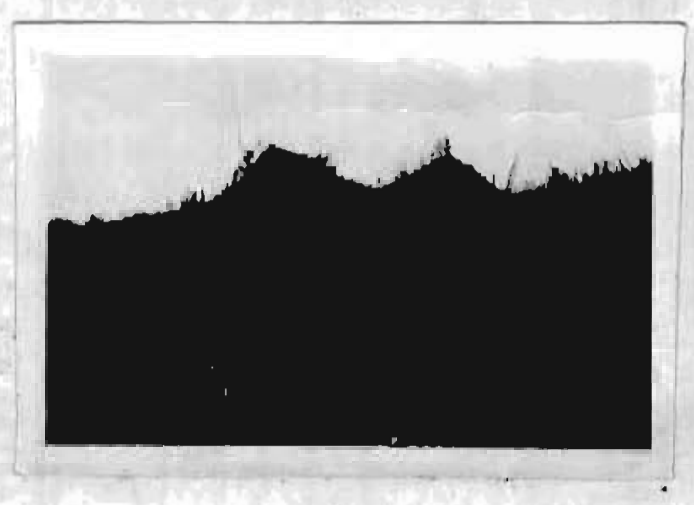

Mound on Ruby-Long Road.

There are no outcrops of igneous rocks discemible. It

is believed that the mound represents an old spring deposit. The mound is approximately twenty five feet high and one hundred feet long. The top is in the form of an oval depression. From a fox hole the character of the interior of the mound resembled silt. The occurrence of similar mounds has been mentioned in Bulletin 754, U. S. G. S., pages 9 and 40 . 
QUARTZ PROSPECT, TUKON RIVRR

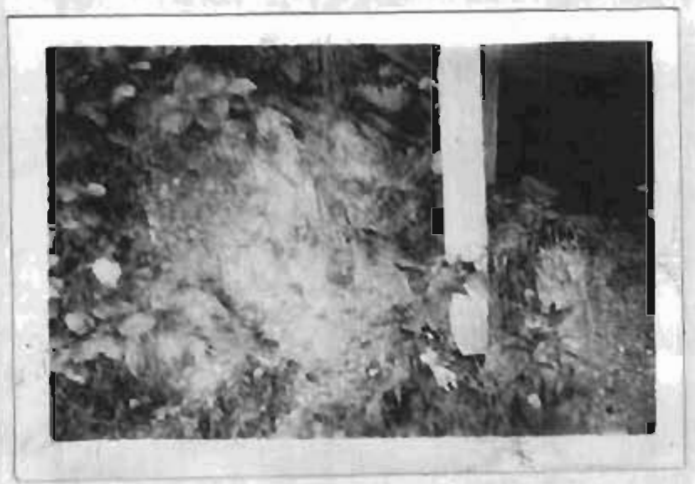

Quartz outcrop near Ruby.

A quarts outcrop, twelve feet in width, occurg five miles above Ruby on the south bank of the Yukon River. The remains of an old prospect drift can be seen. As the drift is eaved only an observation of the outcrop is possible. The strike is north south and the we.lls are irregular. A gently sloping hill rises from the river. The hill is entirely covered with deep moss which is frozen within a foot of the surface. Very little mineralization is seen in the quartz, some specks of pyrite were noted. The quartz is decomposed in the outcrop, showing a yellowish stain. Three samples were taken at the outcrop; namely, two six foot samples across the vein, and a picked sample showing the most pyrite. The samples were assayed by Mr. Paul Hoplcins, Bureau of Kines, Falrbanks. Fech sample gatre an assey return of trace trace for gold and silver. The history of the prospect was not available. (Rejuited abemelened is oyeurs ayer. 
MENDORITE

lir. Harry Bolend of Rabje secured a sample of a mineral near the head of the Novikaket River (the Novikaket and the Nowitna are the sarae stream) which has been identified as mendozite by lir. Hopkins. It is reported to occur as a cappine for a coal vein. A briep description of the mineral is found in Won-lietalic Winerals, Occurrence, Preparation, and Utilization," by Raymond B. Ladoo. Mitendozite is a hydrous sulphate of sodium and aluminum, or a natural soda alum, having the formula $\mathrm{Na}_{2} \mathrm{SO}_{4} \cdot \mathrm{Al}_{2}\left(\mathrm{SO}_{4}\right) 3 \cdot 24 \mathrm{H}_{2} \mathrm{O}:-\mathrm{Na}_{2} \mathrm{SO}_{4}$, 15.5 per cent; $\mathrm{Al}_{2}\left(\mathrm{SO}_{4}\right)_{3}, 37.3$ por cent; $\mathrm{H}_{2} \mathrm{O}, 47.2$ per cent. Hendozite Is an uncommon mineral, resombling ordinary alum, and is found at Mendoza, Argentina, the type locality."

Brush and Penfield list the physical properties of mendoatto as follows: Color, white; Luster, silky-vitreous; Frachure, fibrous; Hardness, 3; Specific Gravity, 1.88. Dana states that the crystallization is Isometric, and that the mineral is soluble in vater. As the mineral is rare in occurrence a sample was forwarded to the Junear office of the United States Geological Survey. Mhe quantity of the mineral available is not determined. No commercial value is known for the mineral. It is sugsested that, vere a large deposit available, mendorite rifght be used in the manufactore of sulphuric acid. 
COAT

Coal is reported to occur under the mendoztte on the Novikaket River. No specimens or further data were available.

Hr. John Inann, of Ruby, reports an occurrence of coal on the Helozi Kiver twelve miles distant, overiand, from Ruby. It is necessary to make the trip by water due to the swampy nature of the country. Whe gwift mater of the upper hielozi is difficult to travel in a poling boat. OIL

liany Alaska newspapers published a report, this spring, of the discovery of oil on the Yukon in the vicinity of the Novikaket River by Harry Bolend and Charlie Wolf. The report vas based on rumor. lifr. Boland, a prospector of the highest type, discotered a black consolidated sand on the Novikaket River. With a mineralogical outfit he mado a few simple tests to try and agcertain the nature of the sand. Sulphuric acid dissolved the black matertal leaving a siliceous residue. The addition of ammonia gave a vhite precipitate. rine oil romor started as a result of some one present saying the precipitate resembled paraffin. The black rineral in the sand was probably due to manganese. lir. Boland or lir. Wolf lenew nothing of the publicity that came from their experiment. 
PLACER OPRRATIONS RUBY DISTRICT 1926

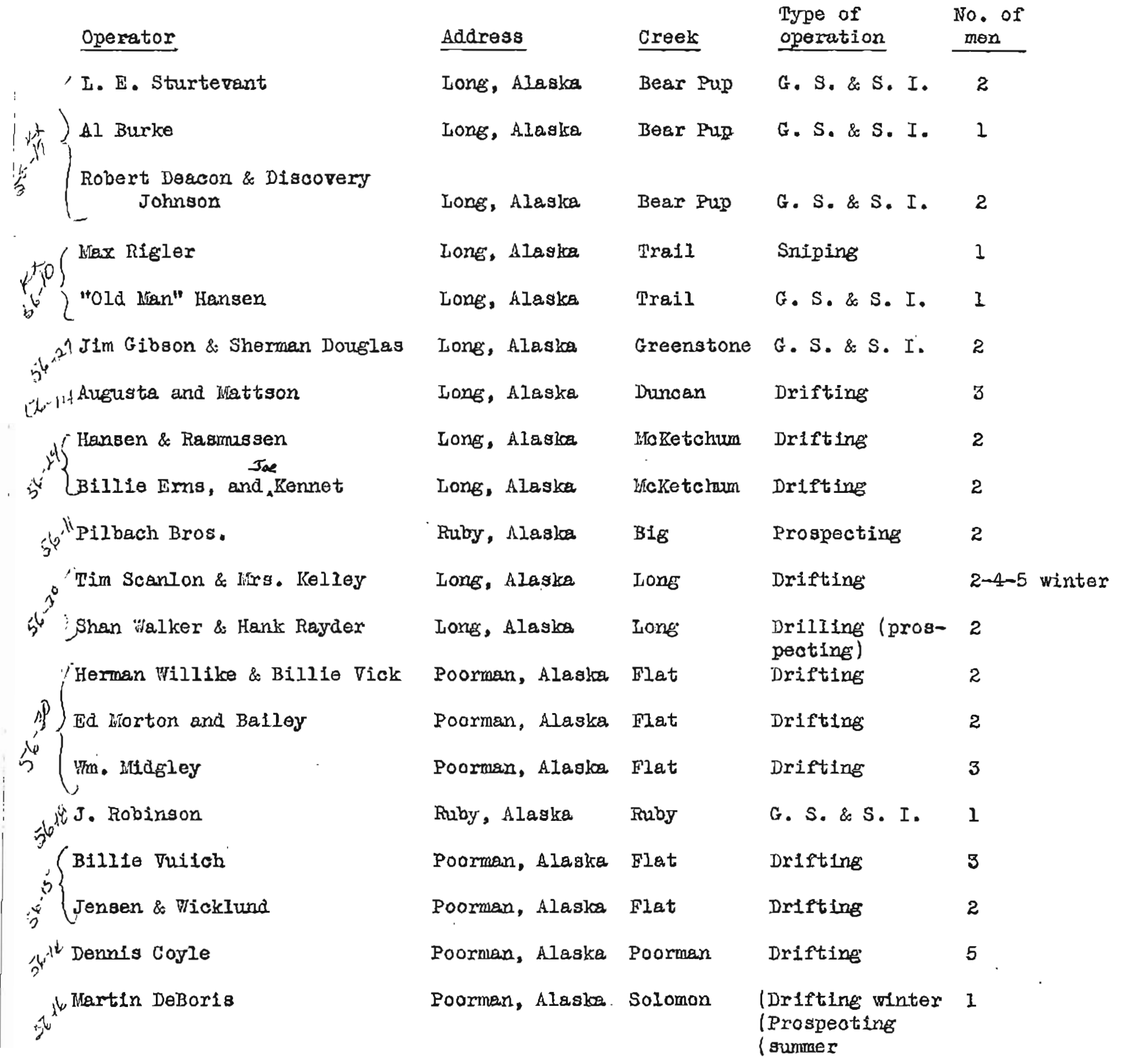


PLACER OPERATIONS RUBY DISTRICT 1926 (CONt.)

Operator

Tozy Cennon

Goo. B1ttles

Grogan \& McGintigan

W. D. McCerty

Coling

Jack Wolf

Joe st. Germain

\begin{tabular}{|c|c|c|c|c|}
\hline Address & & Creek & $\begin{array}{l}\text { Type of } \\
\text { operation }\end{array}$ & $\begin{array}{c}\text { 15o. of } \\
\text { men }\end{array}$ \\
\hline Poorman, & Alaska & Solomon & Prospecting & 1 \\
\hline Poorman, & Alaska & Inionight & Prospeating & 1 \\
\hline Poomman, & Alasta & Timber & G. S. & 2 \\
\hline Poorman, & Alaska & Spruce & Snipine & 2 \\
\hline Poorman, & Mlaska & Tamarack & Sniplng & 1 \\
\hline Poorman, & Alogka & $\begin{array}{l}\text { Granite } 170 \\
\text { mfles from } \\
\text { Poormen upp } \\
\text { Ifttle Sula }\end{array}$ & $\begin{array}{l}\text { Prospeating } \\
\text { er } \\
\text { tns) }\end{array}$ & 1 \\
\hline Poormen, & Alaske & Granite & Prospectins & 1 \\
\hline
\end{tabular}

15. of

1

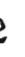

2

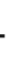

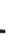


NOTES ON PLACER OPERATION, RUBT DISTRICT, 1926.

Placer operation in the fruby District has been retarded by the dry season and consequent shortage of water. The operations have not been continuzus and plecer interest seens to be waning. There is a hope locally, however, this attention may be brought to the dredging possiblitites in the vicinity of Long Creek. It is reported that some of the owmerg would require a large advance payment for the privilege of prospecting their ground with this end in view. In the oplnion of the other owners this seems to be the only drawback to the active interest in the project. There have been no new discoveries recorded.

Two samples wore taken of the quartz stringers in the schist bedrock at Long. Throughout the Ruby District there are many of these stringers and the samples were taken merely as an indication of the gold content. The first was taken from the Windy Bench Claim omed by Shan Walker, and the second from the clalk held by Al Burke on Bear Pup. Both samples gave an asgay retarn of trace trace for gold and silver. These quarta stringers range frou a few inches to several feet in vidth.

Soine years ago, on the benk of the Yukon about a mile above i. Puby, gold was discovered. About elghty dollars was pamed from the beach. Directly above this point are a number of quartz stringers in the schist. They showed a mineraliation of pyrite and micaceous hemetite. It was not possible to raise a color in the pan around the outcrops. It has been suggested that the gold on the beach ray have come from a lost pole of earlier days.

The placer operation on Ruby Creek, in Ruby town, is of minor importance. The only activity at Long is centered on Bear Pup. The Sturtevants have done a good deal of development rork preparatory to groundsluicing their property when there is sufficient water. Deacon and Johnson, and Al Burke are carryins on suall shovelins in operations. Shan Walker and Hank Rayder are drilling at odd tines on Long Creek. The drifting operations listed were progressing well. The remaining operations in the vicinity of poorian and Jong vere idle at the time of visit due to the ohortage of vater.

The road from Ruby tow has been extended to Greenstone and excellent progress is beinf mado toward Pooman. The Alaska Road Commission have maintained a crew throuenout the summer on the road. It is thought that the ultinate result of the constraction of this road will be an aid to placer' development between Iruby and Ophir. 


\section{Plaoer Minlag Ruby District}
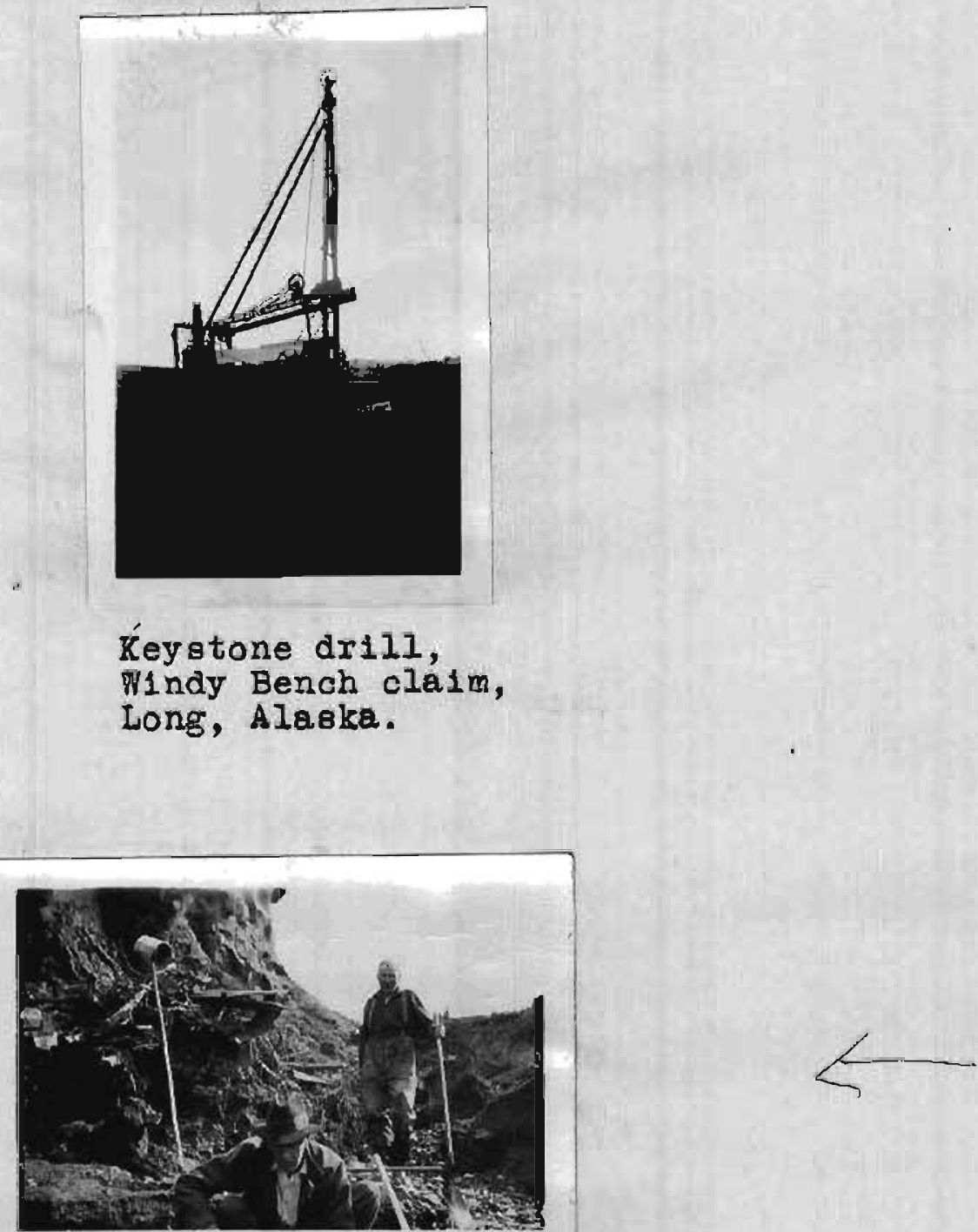

Sturterant'o placer oamp, Bear Pup Creek, Long, Alaska. 